to a change in approash to organic chemistry, which now is manifest both in tho terminology and teaching of the subject, and at the forefront of progress in the fiold.

His first invostigations at University College, London, wore in the field of nucleophilic displacement and olimination reactions. 'Ihe simple concept that several limiting mechanisms for such reactions could be identified and characterized kinetically led quickly to the recognition of fundamental patterns of behaviour which until then had been obseured by apparently conflicting observations. Perhaps the major triumph of this period was the elucidation of the main factors determining whother racemization, retontion or inversion accompanies nucleophilic displacement at a saturated carbon atorn-the problem of the 'Walden inversion'. His brilliant roviews in the Discussions of the Faraday Sociely in 1937 and 1941 still provide the fundamental basis of any mochanistic account of these reactions. Thoy anticipate also many of the later dovelopments in this field; stereochemical, struc. tural and environmental factors, determining the courso of these reactions and the rearrangements which can accompany them, are all discussed in these early summaries, though the elaboration of details requirod many years of later investigation, to which he and his associates no less than other workers in the field have since contributed.

From 1939 he was one of a very small staff maintaining the Department of Chemistry of University College, London, through its evacuation to Aberystwyth and Bangor. In 1943 he was appointed to the ehair of chem. istry in the University College of North Wales at Bangor where he had first studied. There he spent five yoars, and was responsible for the rapid post-war rebuilding and expansion of his Department. At the same time he gathered around him a group of enthusiasts in the application of isotopes to the study of reaction mochanisms. Their pioneering work on the large-scalo separation of the heavy isotope of oxygen now has fruitful offshoots in several departments and countries.

Through this period, Hughes maintained his interest and participation in the work in progress in the Chemistry Departmont of University College, London. His direct and critical approach led during these years towards simplification of the interpretation of the kinetic forms observed for aromatic substitution, and to the genoral acceptance of the view that the nitronium ion is the most important entity involved in aromatic nitration.

In 1948 he was appointed professor of chemistry at University College, London: Here he remained until his death. His scientific distinction was markod in 1949 by his election to fellowship of the Royal Society. In $196 \mathrm{I}$ he became head of the Department of Chemistry at University College, London. His contributions to the olucidation of reaction mechanism ranged in these years over a wide field. He initiated important and imaginative studies of structural and stereochemical effects in nucleophilic and aliphatic replacement reactions; of WagnerMeerwein and related rearrangements; of anionotropic rearrangements; of electrophilic aromatic and aliphatic substitution; of aromatic rearrangements; and of prototropic shifts. Alongside these developments he maintained a policy of encouraging and fostering independence in his younger colleagues, who owe a great debt to his generosity and to his faith in their ability and promise.

In 1961 he undertook editorship of a series of monographs to be published by Elsevier on special topics in physical organic chemistry; the first of these was at the proof stage at the time of his death.

His sorvices to acadomic life, which were marked by his elcetion to fellowship of the University of Wales and of University College, London, were by no means solely in the field of research. A valued teacher and colleague both at Bangor and at University College, London, where he was dean of the Faculty of Science from 1958 until 1961 , he contributed also in a most valuable and important way as an appointed teacher of the University of London, particularly through his ehairmanship (1955-60) of the University Board of Studies in Chemistry. Here his wise and efficient guidance gained him many friends, and he will be much missod from the academic councils of the University during the times of ehange ahead. He was greatly in demand as external examiner for first degrees and for highor degreos of universities throughout Britain. He porformed an extromely important task as honorary secretary (1949-61) and then as chairman of tho Advisory Council of the Ramsay Memorial Fellowship Trust; and on committees of solection for Imperial Chemical Industries, Ltd., and other senior research fellowships, where his judgment, common-sense and powers of assessment were regarded highly.

Outside the University he played many important parts. Ho was a governor of tho Northern Polytechnic (1950 60). He was a Fellow (1938) and momber of the Council (1961-63) of the Royal Institute of Chemistry, and acted for the Institute as assessor in organic chemistry for Higher National Certificates and Diplomas, and as a special examiner; he was honoured by the Society as a Meldola Medallist in 1936. Perhaps his greatest contribution, however, was to the Chemical Socioty, to the publications of which he personally contributed so much. He served on almost every sub-committee of this groat Society, being ehairman of the Library Committee from 1959 onwards, an honorary secretary from 1950 until 1956 , and a vice-president (1956-59). He was honorary secretary of the Chemical Council (1953-55).

Hughes's scientific lifotimo has scen an onormous change in organic chemistry. All its many aspects have been affected by the roalization that the complicatod patterns of yield and reactivity can be interpreted and already in part predicted in terms of the accessibility of the various transition states leading from starting-materials to products. Few have contributed to the acceptance of this approach, bitterly contested as it has been, more than Hughes. His work has always been characterized by steadfast belief in the importance of mechanistic investigations, an insistence on experimental verification of each point as it has come under scrutiny, and an intuitivo recognition of the quality of crucial experimental observations.

Ho was a man of outstanding humanity. His actions and his advice led directly to the heart of any problem through clear recognition of general principles. His friends will remombor him for his doep sonse of loyalty; for his unshirking sense of responsibility; and for his devotion to the Department where so much of his work was done.

In 1934 he married Ray Fortune Christine, daughter of the Rev. Ll. Davies, of Brecon. She survives him with their daughter.

P. B. D. DE la MARE

\section{Dr. Annie Porter}

PARAsitologists the world over will mourn the loss of Annie Porter, who died in London at the advanced age of cighty-throo on May 9, after a protracted and debilitating illness.

Born at Shoreham-on-Sea, Sussex, on February 20, 1880 , Annie was the elder daughter of Samuel Porter. The family early moved to Brighton whoro sho recoived her school education, whence she proceeded to University College, London. 'There her first love was mycology - a subject in which she retained an interest throughout hor lifoalthough animal parasitology, and especially protozoology, domanded most of her professional time in later years.

From University College she procoodod in 1914 for a time to the Quick Laboratory in Cambridgo, where she mot and worked with H. B. Fantham (and whom she married in 1915). At Cambridge Dr. Porter hold a Boit Memorial research fellowship for two years and tanght as an assistant helminthologist. 
In 1917 she accompanied hor husband to Johannesburg and became head of the department of parasitology in the South African Institute for Medical Research, serving also as senior lecturer in parasitology in the University of the Witwatersrand and as examiner in zoology and animal parasitology at both institutions. She remained in South Africa until 1933 when she accompanied her husband to Canada, where she remained until 1938 as research associate in zoology at McGill University, Montreal. On the death of her husband (during Oetober 1937) she was invited by the secretary of the Zoological Society of London (Dr. (now Sir) Julian Huxley) to become honorary parasitologist at Regent's Park, a post she filled with great success until a few months prior to her death.

The furtherance of zoology and especially animal parasitology was almost the sole interest in Annie Porter's long life. Always ready to help anyone interestod in animals, she will long be remembered by her many pupils and friends who are now widely scattered over the globe. Her dedication to zoological science transcended all other interests and amounted to a passion when stimulating her co-workers in the several team projects with which she was associated.

Hor early interest in mycology found expression during the lean periods of the Second World War when she combed the areas around her home for edible fungi, samples of which she generously bestowed on her friends. She spent long hours propagating the edible species by spreading their spores in suitable localities in Regent's Park.

Apart from her scientific work Dr. Porter devoted her time to social welfare and particularly to the education of spastic children, for whom once a year she borrowed live animals from the Zoo for demonstration.

Out of her large estate in Great Britain, Dr. Yorter willed £1 0,000 to Christ's College, Cambridge, to endow a research scholarship in animal parasitology and protozoology, $£ 5,000$ each to University College and to the Zoological Society of London for similar research scholarships, besides $£ 5,000$ to the Univorsity of the Witwatersrand for a research scholarship "to be held in any University in the British Empire" and $£ 1,000$ to McGill University for a research scholarship. W. C. Osman HiuI

\section{NEWS and VIEWS}

The U.S. National Science Foundation:

\section{Dr. Alan T. Waterman}

ON the retirement of Dr. Alan T. Waterman as first director of the National Science Foundation, the three Presidents of the United States under whom he had served paid tribute to his skilled leadership in establishing the Foundation and guiding it through the crucial years of its existence as a Federal agency in support of basic research and education in the sciences. The statements of the three Presidents, as well as tributes from the scientific community, were read at a dinner given for Dr. and Mrs. Waterman by the National Science Board on June 21, 1963. President Kennedy observed: "Through the work of the Foundation in sponsoring basic research, the Nation has embarked on exciting and critical adventures in science that will contribute importantly to human progress. The NSF has helped extend our horizons to the innermost workings of man and his society and the outermost reaches of our planet and the universe". Dr. Waterman, who continues as a consultant to the Founda. tion, is also president of the American Association for the Advancement of Science, and next year will become chairman of the Board of Directors. Dr. Waterman has deferred for the time being further plans for the future until he avails himself of the holiday which he consistently neglected in order to devote himself to the work of the National Science Foundation.

\section{Dr. Leland J. Haworth}

Dr. Leland J. Haworth succeeded Dr. Alan T. Waternan as director of the National Science Foundation on July 1. He has been one of the five commissioners of the U.S. Atomic Energy Commission since 1961. Prior to his appointment as commissioner, Dr. Haworth was associated with the Brookhaven National Laboratory, one of the United States' major facilities devoted to highenergy physics. He became director of the Laboratory in 1948 , and in 1960 he was, in addition, made president of Associated Universities, Inc., a non-profit corporation of nine eastern universities which operates the Laboratory for the U.S. Atomic Energy Commission and the National Radio Astronomy Observatory for the National Science Foundation. A native of the Middle West, Dr. Haworth was educated at the University of Indiana, where he received his A.M. degree, and at the University of Wis- consin, where he was awarded his doctorate in physics in 1931. During 1938-47 he was professor of physics in the University of Illinois. During the Second World War he was on leave of absence from Illinois to work on radar development at the Radiation Laboratory of the Massachusetts Institute of Technology. Dr. Haworth's intimate knowledgo of Government research and development problems has been further enhanced by membership of a number of advisory committees and panels. His most recent personal research interests include high-energy physics, and high-energy accelerator design. In earlier years he worked on secondary emission of electrons, Joule-Thomson effects at very low temperatures, nuclear physics, and electronics.

\section{Mathematical Physics at Birmingham:}

Prof. T. H. R. Skyrme

Mr. T. H. R. Skyrme has been appointed to the chair of mathematical physics at the University of Birmingham as from October 1, 1964. Mr. Skyrme succeeds, as professor and head of the Department of Mathematical Physics, Prof. R. E. Peierls, who has been appointed Wykeham professor of physics in the University of Oxford (see Nature, 196, 1038; 1962). Mr. Skyrme's academic career started with scholarships at Eton and at Trinity College, Cambridge, where after taking a double first in mathematics he became a Fellow of his College. During the Second World War he was with Prof. Poierls for two years as a membor of a British mission sent to work with American scientists in New York and later in New Mexico; he returned to the United Kingdom with Prof. Peierls as a Research Fellow in the Department of which he is now to be the head. Here he met and married Dr. Dorothy Millest, at that time lecturer in the Department of Physics. Since leaving Birmingham in 1948, Mr. Skyrme and his wife have been on the staff of the Atomic Energy Establishment, Harwell, except for two years when he held fellowships at the Massachusetts Institute of Technology and Princeton, a period when he was a visiting professor at the University of Pennsylvania, and the time since 1962 when they have been teaching at the University of Malaya. Thus Mr. Skyrme, who is aged forty, goes to Birmingham in 1964 with experience of eight universities and research institutes in three continents. He has carried out research in the theory of atomic nuclei and of sub-nuclear particles, especially in field theory. 